\title{
One century of vegetation change on Isla Persa, a nunatak in the Bernina massif in the Swiss Alps
}

\author{
Vittoz, Pascal $^{1^{*}}$; Bodin, Jeanne ${ }^{2,3}$; Ungricht, Stefan ${ }^{4}$; Burga, Conradin A. ${ }^{5}$ \& Walther, \\ Gian-Reto $^{2,6}$
}

${ }^{1}$ Faculty of Geosciences and Environment and Department of Ecology and Evolution (Faculty of Biology and Medicine), University of Lausanne, Bâtiment Biophore, CH-1015 Lausanne, Switzerland;

${ }^{2}$ Institute of Geobotany, Leibniz University of Hannover, Nienburger Str 17, D-30167 Hannover, Germany; ${ }^{3}$ UMR INRA-UHP 1137 Forest Ecology and Ecophysiology Unit, Phytoecology team, INRA

Nancy, F-54280 Champenoux, France; ${ }^{4}$ University of Zurich, Institute of Systematic Botany, Herbarium, Zollikerstrasse 107, CH-8008 Zurich, Switzerland; ${ }^{5}$ Department of Geography, Physical Geography Division, University of Zurich-Irchel, Winterthurerstr. 190, CH-8057 Zurich, Switzerland;

${ }^{6}$ Department of Plant Ecology, University of Bayreuth, D-95440 Bayreuth, Germany.

"Corresponding author; Fax +41 2169242 65; E-mail: pascal.vittoz@unil.ch

\begin{abstract}
Question: How did the vascular plant species composition of a nunatak in the alpine vegetation belt change over a time span of one century?

Location: A $0.056-\mathrm{km}^{2}$ nunatak, Isla Persa in the Swiss Alps, that remained ice free during the last maximum glacier advance in the 1850 s and is today partly covered with climactic alpine grassland and dwarf heath shrubs.
\end{abstract}

Methods: Floristic inventories in 1906, 1927, 1972, 1995, 2003 and 2004 and a comparative analysis of the species composition over the period 1906-2004.

Results: Thirty-one species that were not recorded in the first inventory were found in the following surveys. However, among them only six were common by 2004. On average, the new species prefer warmer conditions than those previously present and most newcomers are associated with montane or subalpine grasslands and woodlands. In particular, the observed increase of Vaccinium myrtillus and the arrival of shrub and tree species further substantiate a trend towards vegetation composition of the lower altitudinal belt. Ferns represented $24 \%$ of the newcomers, probably due to the high dispersal ability of their lightweight spores. The observed species enrichment was globally small compared to previously inventoried summits.

Conclusion: Floristic change strongly suggests warmer climatic conditions as the main factor contributing to species compositional change. The relative stability of species richness may be explained by several factors: the isolation of the nunatak and the difficulties for plants to reach the site, the colder local climate, a limited available species pool and interactions of established alpine plants with newly immigrating taxa. Supplementary data collected at about the same altitude would be necessary to better understand the influence of climate change on alpine grasslands.

Keywords: Alpine vegetation, Global warming, Long-term monitoring, Plant traits, Species diversity, Switzerland 


\section{Introduction}

Climate warming induces upward range shifts of plant species in mountain areas. This trend was predicted by numerous studies (e.g. Gottfried et al. 1998; Guisan \& Theurillat 2000; Dirnböck et al. 2003) and it has also been substantiated by observations on many high alpine, rocky summits (Braun-Blanquet 1957; Hofer 1992; Grabherr et al. 1994, 1995; Burga et al. 2004; Walther et al. 2005a; Vittoz et al. 2006; Parolo \& Rossi in press), by single species re-surveys (Dobbertin et al. 2005; Walther et al. 2005b), and by altitudinal shifts of the treeline ecotone (Kullman 1986; Taylor 1995; Moiseev \& Shiyatov 2003; Camarero \& Gutiérrez 2004; Vittoz et al. in press; for a review see Walther 2004). However, data for long-term vegetation changes in subalpine or alpine grasslands are lacking (for shorter time scales see Kudernatsch 2005). Sufficiently long time series of permanent plots are few or unavailable for studying upward range shifts of mountain plants due to anthropogenic disturbances.

In the Alps, the glaciers reached their last maximum extent in the 1850s (see references in Burga 1999) and have since then been shrinking. The rate of glacier retreat has increased further in the last few decades (Paul et al. 2004). In previous centuries throughout the Holocene period, the extent of the glaciers of the Alps is assumed to have reached the 1850 maximum but never substantially exceeded this level (Maisch et al. 1999). Hence, isolated rocks surrounded by glaciers in 1850 , called nunataks, may at least be partly covered with ancient soils and with vegetation in climax states.

Isla Persa (literally the "lost island" in Rhaeto-Romanic) in the Eastern Swiss Alps is such a nunatak in the alpine belt. It remained ice-free during the last maximum of the local glaciers (Fig. 1; Lechner 1858) and is covered with large patches of climactic alpine grasslands. The nunatak is an interesting area for vegetation studies due to its isolation from intensive anthropogenic disturbance, and has therefore attracted the interest of botanists since the early $20^{\text {th }}$ century.

The first floristic inventory of this nunatak was published in Rübel's monograph (1912) on the vegetation of the Bernina region, named after the highest mountain peak (Piz Bernina $4049 \mathrm{~m}$ a.s.1.) of the Eastern Alps. The nunatak was revisited three times in $20^{\text {th }}$ century but the inventories remnained partly unpublished (Flütsch et al. 1930; De Haas 1973; Ungricht 1995). With the present article, we wish to compile all of this previous historic data and integrate two recent inventories. Altogether, these inventories provide a rare opportunity for the analysis of vegetation change in alpine grasslands during the course of one century. Specifically, we address the following questions: (i) how much has the floristic species richness changed through time, (ii) is climate change likely to be responsible for the observed development, and (iii) which are the biological traits linked to the observed colonization process?

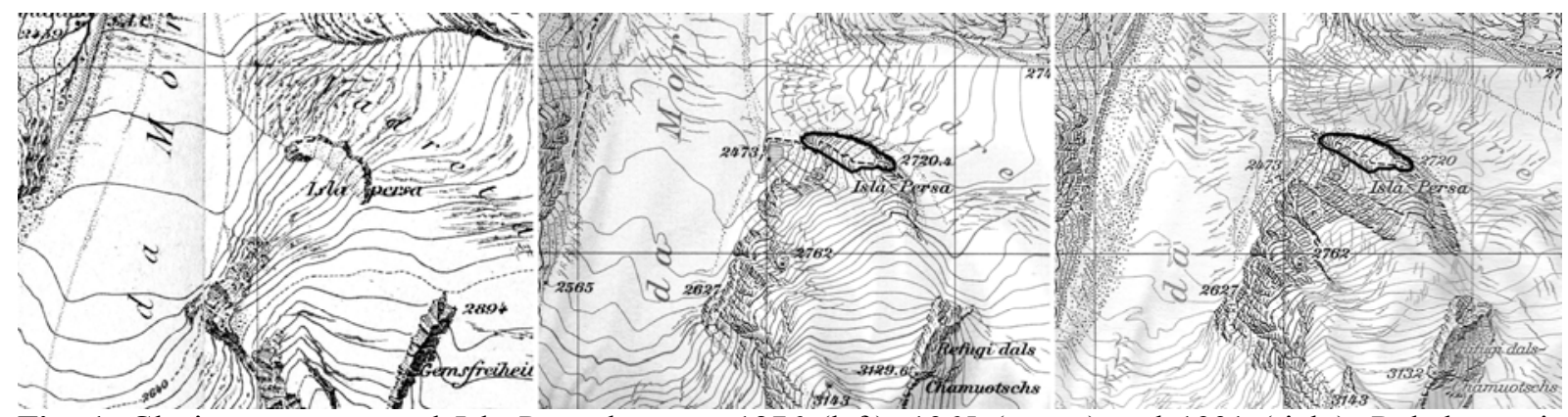

Fig. 1. Glacier retreat around Isla Persa between 1876 (left), 1965 (centre) and 1991 (right). Rübel area is delimited by the Morteratsch glacier to the West, the Pers glacier to the North and East, and the Fortezza glacier to the South in 1876 and by the black line in 1965 and 1991. Swisstopo, Siegfried map n521 at 1:50'000 in 1896, Landeskarte $\mathrm{n}^{\circ} 268$ in 1965 and 1991 at 1:50'000 with a grid size of $1 \mathrm{~km}$. Reproduced by permission of swisstopo (BA071283). Isla Persa extends now on the whole rocky area (grey part in the south of the Rübel area). 


\section{Study area}

The investigation area, a nunatak named Isla Persa $\left(46^{\circ} 24^{\prime} \mathrm{N}, 9^{\circ} 56^{\prime} \mathrm{E}\right)$, is delimited to the West by the Morteratsch glacier, to the North and East by the Pers glacier and to the South by the Fortezza glacier (Fig. 1). At present, the altitudinal range of the Isla Persa spans $400 \mathrm{~m}$, between 2450 $\mathrm{m}$ and $2850 \mathrm{~m}$ a.s.l., which is entirely within the alpine belt $(2300-3000 \mathrm{~m}$ in the region). Isla Persa is isolated from the surrounding ice-free areas by $500 \mathrm{~m}$ to the North and $900 \mathrm{~m}$ to the West. It is very unlikely that it was ever permanently inhabited and grazed by domestic cattle or sheep. However, the nunatak is now frequently visited by hikers crossing the ice-free area between the two adjoining glaciers.

The nunatak belongs to the lower Eastern-Alpine Bernina nappe s.l. The rocks consist mainly of granites, granodiorites, diorites, and gabbros (Büchi 1994). A large part of the Isla Persa represents a granitic rock outcrop partly covered with screes. The vegetation consists of scattered alpine grasslands and some heath dwarf shrubs on well-developed alpine regosols and leptosols, especially on the southern foot area of the nunatak.

At the time when it was first investigated in 1906 by Rübel (1912), the Isla Persa covered about $0.056 \mathrm{~km}^{2}$ and comprised altitudes between 2510 and $2720 \mathrm{~m}$ a.s.l. Since then, the ice-free surface has increased to ca. $0.68 \mathrm{~km}^{2}$ as a consequence of a rapid glacier retreat (Fig. 1). However, since the 1940s, the total area of the nunatak can no longer be clearly delimited because another icefree rocky area merged at its southwestern corner making it extend to $3143 \mathrm{~m}$ a.s.l.

The closest meteorological station is located in Sils-Maria, at $1802 \mathrm{~m}$ a.s.1., $15 \mathrm{~km}$ to the West of Isla Persa. Both sites are located in the Inner Alps, which have low precipitation and air humidity. Mean annual temperature $( \pm 1 \mathrm{SD})$ for the $1961-90$ period was $1.6 \pm 0.5^{\circ} \mathrm{C}\left(-7.2 \pm 1.9^{\circ} \mathrm{C}\right.$ in January and $10.4 \pm 1.2^{\circ} \mathrm{C}$ in July) and the average annual precipitation was $978 \pm 168 \mathrm{~mm}$, with drier winters (mean of the sum for December to February $143 \pm 61 \mathrm{~mm}$ ) than summers (June to August $335 \pm 98$ $\mathrm{mm}$ ). During the $20^{\text {th }}$ century, a general temperature increase during the growth season (MaySeptember) occurred between 1918 and 1951, a decrease was observed till 1974, and since then an increase has again been observed (Fig. 2) in accordance with other regions in Switzerland (Bader \& Bantle 2004). However, the temperature increase was altogether lower in Sils-Maria than in other Swiss regions: $+0.4^{\circ} \mathrm{C} / 100$ years in summer for the period $1864-2001$ compared with $+0.6-0.9^{\circ} \mathrm{C} / 100$ years for the lowland and Northern Alps (Bader \& Bantle 2004). Like in all other regions, most of this increase took place in the last decades and the mean annual increase was similar to records for the Northern Hemisphere (Rebetez \& Reinhard in press).

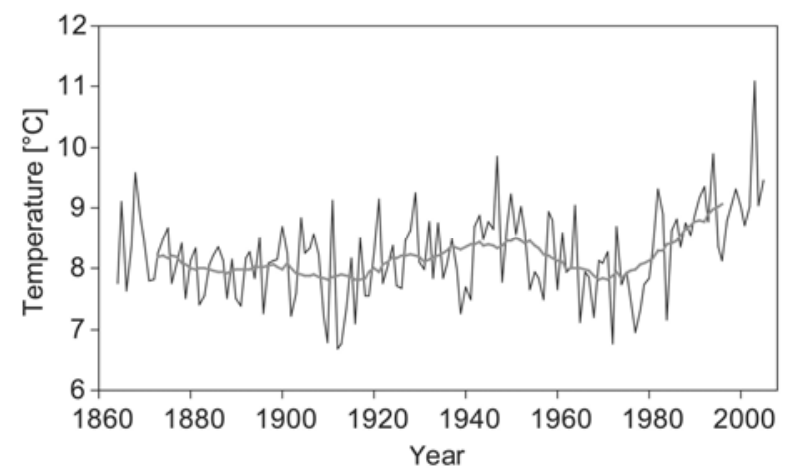

Fig. 2. Average growth season (May-September) temperature in Sils-Maria (1802 m a.s.1., $15 \mathrm{~km}$ from Isla Persa; data MeteoSwiss). The grey line is the 20 -yr mobile average.

\section{Methods}

Field plant inventories

A set of six consecutive plant species inventories of the Isla Persa area was available, spanning the period of one century (Tab. 1). Two inventories were made in the first half of the $20^{\text {th }}$ century by Rübel (1912) in 1906 and Braun-Blanquet in 1927 (Flütsch 1930), followed by two inventories in the second half of the $20^{\text {th }}$ century (De Haas 1973; Ungricht 1995). In 2003 the full ice-free area was again 
inventoried by two of the authors (Walther, Burga and collaborators). In 2004, a further inventory took place by another author (Vittoz), which was restricted to the originally ice-free core area of the nunatak, i.e., the same area as originally inventoried by Rübel (here designated as Rübel area, Tab. 1). The different inventories were accomplished by varying numbers of observers over varying numbers of days, hence with different levels of assessment effort. However, all included the most favourable period as judged by the phenology of alpine plants. At all inventories only the presence of the species was recorded, with occasional indications for rare species, except the last inventory (2004) by which abundance estimates to classes were provided (Tab. 2; cf. Grabherr et al. 2001) and data about plant location and substrate was recorded for most of the rarest species.

Table 1. Authors, dates, assessment areas, number of observers, assessment time and recorded species numbers of the six inventories on Isla Persa (Swiss Alps). All but the last author inventoried the complete ice-free area, which increased through time. The area inventoried by Rübel in 1906 is here defined as the "Rübel area" and used for the analyses in this paper. The corrected number of species incorporates the potentially overlooked species observed by a previous and the following inventory. The two last inventories were merged as they were separated only by one year.

\begin{tabular}{|c|c|c|c|c|c|c|c|c|}
\hline \multirow[t]{2}{*}{ Author } & \multirow[t]{2}{*}{$\begin{array}{c}\text { Date of } \\
\text { publication }\end{array}$} & \multirow[t]{2}{*}{$\begin{array}{l}\text { Date of } \\
\text { inventory }\end{array}$} & \multirow[t]{2}{*}{$\begin{array}{c}\text { Inventoried } \\
\text { area }\end{array}$} & \multirow[t]{2}{*}{$\begin{array}{l}\text { Number of } \\
\text { observers }\end{array}$} & \multirow[t]{2}{*}{ Time used } & \multicolumn{3}{|c|}{ Number of recorded species } \\
\hline & & & & & & $\begin{array}{c}\text { inventoried } \\
\text { area }\end{array}$ & Rübel area & $\begin{array}{c}\text { corrected for } \\
\text { Rübel area }\end{array}$ \\
\hline Rübel & 1912 & 1906 & $\begin{array}{l}\text { Ice-free area } \\
=\text { Rübel area }\end{array}$ & $1 ?$ & $?$ & 98 & 98 & 98 \\
\hline Flütsch & 1930 & 1927 & Ice-free area & 27 & 1 day & 103 & 99 & 106 \\
\hline De Haas & 1973 & $1971-72$ & Ice-free area & several & 44 days & 134 & 116 & 118 \\
\hline Ungricht & 1995 & 1994-95 & Ice-free area & $1-4$ & 40 hours & 110 & 99 & 117 \\
\hline Walther \& Burga & & 2003 & Ice-free area & $3-4$ & 7 days & 136 & 115 & 126 \\
\hline Vittoz & & 2004 & Rübel area & 2 & 3 days & 122 & 122 & 120 \\
\hline
\end{tabular}

By comparing the two last inventories and previous indications of species location, we established a comparative species list for the Rübel area and a list of additional species from the newly deglaciated area (App. 1, supplementary archives). For each inventory it was possible to obtain a comprehensive species list for the Rübel area, but the data were inadequate to get species lists for the newly ice-free area. Therefore, we limited our study to the Rübel area.

The species names follow Aeschimann et al. (2004). From the different species lists, the following species were merged because of suspected misidentifications: Avenella flexuosaDeschampsia caespitosa; Adenostyles leucophylla-A. intermedia; Carex frigida-C. ferruginea; Galium anisophyllon-G. pumilum; Poa supina-P. annua-P. badensis; Poa laxa-P. minor and Sagina saginoides-S. glabra.

\section{Analyses}

It is likely that some rare and/or inconspicuous species were overlooked in all inventories (Vittoz \& Guisan 2007). Hence, species present in an earlier inventory that lacked confirmation in an intermediate inventory, but were "rediscovered" in a later survey were considered present throughout the entire interval. It is more likely for a missed species to have been overlooked in the intermediate inventory than for it to have disappeared and re-colonized the area in the given time interval. For the same reason, we assumed that no species disappeared or appeared between 2003 and 2004 and we merged these last two inventories (Tab. 1).

We used biological traits to assess if newcomer species (i.e. species that were found for the first time after 1906) differed from the original species (already present in 1906). Five of the recorded traits were indicative of the ecological conditions under which the species occur. The ecological indicator values (Landolt 1977) vary between 1 and 5 and are available for each Swiss species following its ecological preferences. The soil texture ( 1 , stony -5 , clayey), soil humus content ( 1 , no humus -5 , peaty), soil nutrients content (1, oligotrophic -5 , eutrophic) and temperature (1, alpinenival belt -5 , collinean belt) were used. The sociological classification of species simplified from 
Ellenberg et al. (1991) - or Aeschimann et al. (2004) in case the species is not listed in the former was completed with a more integrative view of the species ecological preferences. The nomenclature for plant sociological units follows Ellenberg et al. (1991). The growth forms were simplified from Pignatti (2005) (therophytes, non-graminoid hemicryptophytes, graminoid hemicryptophytes, geophytes, creeping chamaephytes, chamaephytes in cushions, succulent chamaephytes, woody chamaephytes, phanerophytes). Four traits were related to reproduction. The respective importance of sexual and clonal reproduction was assessed following the BIOLFLOR databank (Klotz et al. 2002) in three categories: sexual reproduction only, sexual and clonal reproduction possible and mainly clonal reproduction. The same reference was used for the fertilization type in five categories: only selffertilization, wind as vector, insects, mainly insects but possible self-fertilization and fern gametophyte fertilization. Data on seeds or weight of other diaspores were taken from Klotz et al. (2002) and Müller-Schneider (1986). Since values were still missing for $29 \%$ of the species, we used seven categories for which unknown species were attributed on the basis of the closest relative species: 1 , diaspore < $0.05 \mathrm{mg} ; 2,0.06-0.2 \mathrm{mg} ; 3,0.21-0.5 \mathrm{mg}$; 4, 0.51-1 mg; 5, 1.01-2 mg; 6, 2.01-10 mg; 7, diaspore $>10 \mathrm{mg}$. Dispersal vector of the seeds followed Müller-Schneider (1986) and dispersal distance of the diaspores was simplified in 7 types following Vittoz \& Engler (in press), which takes into account the main dispersal vector and important species traits influencing dispersal. The types chosen were: 1 when $99 \%$ of the seeds fall $<1 \mathrm{~m} ; 2,<5 \mathrm{~m} ; 3,<15 \mathrm{~m} ; 4,<150 \mathrm{~m} ; 5,<500 \mathrm{~m} ; 6,<1500$ $\mathrm{m} ; 7,<5000 \mathrm{~m} . \chi^{2}$-tests were used in statistical analyses of trait differences.

\section{Results}

During the assessment window of nearly one century, the number of species increased almost continuously in the Rübel area from 98 in 1906 (Rübel 1912) to 126 in 2004 (Tab. 1). However, most of the newly recorded species were rare in 2004 and only some species, which arrived between 1906 and 1927, were locally common in 2004 (Tab. 2). The abundance of Vaccinium myrtillus, Elyna myosuroides and Cerastium uniflorum was relatively high at the last inventory and these species have never been overlooked since their first record (in 1927) making it likely that they immigrated after 1906. Pinguicula leptoceras, Soldanella alpina and Primula integrifolia were present in a particular sector of the nunatak only. These species were also recorded for the first time in 1927. We assumed that although present, they may have been overlooked in the 1906-inventory but nonetheless they are considered to have colonized the nunatak when observed for the first time in 1927.

Among the 31 new species, 10 species were found at a higher altitude in 2004 (Tab. 2) than reported for the whole Bernina region at the beginning of the $20^{\text {th }}$ century (Rübel 1912). These altitudinal shifts were particularly pronounced for Athyrium distentifolium $(+470 \mathrm{~m})$, Diphasiastrum alpinum $(+340 \mathrm{~m})$, Pinguicula leptoceras $(+260 \mathrm{~m})$ and Poa supina $(+120 \mathrm{~m})$ (identification was uncertain for two poorly developed, supplementary species: Dryopteris dilatata and Leontodon autumnalis).

Some species disappeared or were not found after the first observation (Tab. 2). Misidentifications cannot be discounted, but they were rather unlikely. Three of these species (Euphrasia rostkoviana, Gentiana campestris, Thymus serpyllum) occurred close to their highest altitudinal range in the region (Rübel 1912).

None of the ecological indicator values (Landolt 1977) for soil conditions showed differences between species that had recently colonized Isla Persa compared to those present in 1906 (Tab. 3). The mean values ( $\pm 1 \mathrm{SD})$ for 1906-species and colonizing species, respectively, were $3.31 \pm 0.91$ and 3.42 \pm 1.15 for soil texture, $3.27 \pm 0.71$ and $3.42 \pm 0.87$ for soil humus content, and $2.19 \pm 0.71$ and $2.39 \pm$ 0.79 for soil nutrient content. In contrast, the temperature indicator value showed a highly significant difference between inventories, with means $1.53 \pm 0.58$ for the 1906 inventory compared to $2.09 \pm$ 0.53 for the new species (Tab. 3). This corresponded with a continuously decreasing proportion of alpine and nival species (value 1, represented only $9.1 \%$ of the new species) in the inventories and a corresponding increase in subalpine species (value 2, 72.7\% of the new species) and montane or indifferent species (value 3, 21.2\% of the new species; Fig. 3). 
Table 2. Species that have disappeared or were newly recorded on Isla Persa between 1906 and 2004. 1 species present without abundance estimation; * species probably overlooked because present in the previous and following inventory; r! very rare; r rare; s scattered; r-lc rare but locally common; s-lc scattered but locally common (for a complete species list see App. 1 in Supplemental archives). The highest altitudes are the recorded altitudinal limit for the whole Bernina regions in 1906 (Rübel 1912) and for the Isla Persa in 2004. Species sociology is simplified from Ellenberg et al. (1991) or Aeschimann et al. (2004) and the occupied substrate refers to the conditions where the individuals were recorded in 2004.

\begin{tabular}{|c|c|c|c|c|c|c|c|c|c|}
\hline \multirow[t]{2}{*}{ Plant species } & \multirow[t]{2}{*}{1906} & \multirow[t]{2}{*}{1927} & \multirow[t]{2}{*}{1972} & \multirow[t]{2}{*}{1995} & \multirow[t]{2}{*}{2004} & \multirow{2}{*}{\multicolumn{3}{|c|}{$\begin{array}{ll}\text { Highest altitude }[\mathrm{m}] & \text { Sociology } \\
1906 & 2004\end{array}$}} & \multirow[t]{2}{*}{ Occupied substrate } \\
\hline & & & & & & & & & \\
\hline \multicolumn{10}{|l|}{ Disappeared species } \\
\hline Veronica bellidioides & 1 & 1 & 1 & & & 3260 & & Alpine grasslands & \\
\hline Euphrasia rostkoviana & 1 & & & & & 2600 & & Lowland meadows & \\
\hline Gentiana campestris & 1 & & & & & 2700 & & Lowland meadows & \\
\hline Thymus serpyllum & & 1 & & & & 2700 & & Others & \\
\hline Festuca halleri & & & 1 & & & 3400 & & Alpine grasslands & \\
\hline \multicolumn{10}{|l|}{ New species } \\
\hline Vaccinium myrtillus & & 1 & 1 & 1 & s-lc & 2750 & 2520 & Shrubs and forests & Grassland and heathland \\
\hline Elyna myosuroides & & 1 & 1 & 1 & $\mathrm{~s}$ & 3090 & 2520 & Alpine grasslands & \\
\hline Soldanella alpina & & 1 & 1 & $*$ & $\mathrm{~s}$ & 2700 & 2510 & Alpine grasslands & Grassland \\
\hline Pinguicula leptoceras & & 1 & 1 & $*$ & $\mathrm{~s}$ & 2260 & 2520 & Others & Grassland \\
\hline Primula integrifolia & & 1 & 1 & $*$ & r-lc & 3010 & 2510 & Alpine grasslands & \\
\hline Cerastium uniflorum & & 1 & 1 & 1 & r-lc & 3400 & 2660 & Rocks, cliffs, screes & Stones and/or gravel \\
\hline Gentiana brachyphylla & & 1 & 1 & 1 & $\mathrm{r}$ & 3260 & 2560 & Lowland meadows & Grassland \\
\hline Trichophorum cespitosum & & 1 & $*$ & $*$ & $\mathrm{r}$ & 2450 & 2510 & Others & Grassland \\
\hline Antennaria dioica & & 1 & 1 & $*$ & $\mathrm{r} !$ & 3010 & 2560 & Lowland meadows & Grassland \\
\hline Phleum alpinum & & & 1 & $*$ & $\mathrm{r}$ & 2830 & & Alpine grasslands & \\
\hline Sagina saginoides / S. glabra & & & 1 & $*$ & $\mathrm{r}$ & 2550 & 2540 & Alpine grasslands & Stones and/or gravel \\
\hline Asplenium septentrionale & & & 1 & $*$ & $\mathrm{r}$ & 2470 & 2530 & Rocks, cliffs, screes & Cliff \\
\hline Cryptogramma crispa & & & 1 & 1 & $\mathrm{r}$ & 2730 & 2560 & Rocks, cliffs, screes & Stones and/or gravel \\
\hline Polystichum lonchitis & & & 1 & 1 & $\mathrm{r}$ & 2550 & 2540 & Rocks, cliffs, screes & Stones and/or gravel \\
\hline Coeloglossum viride & & & 1 & $*$ & $\mathrm{r}$ & 2650 & 2520 & Lowland meadows & Grassland \\
\hline Trifolium alpinum & & & 1 & 1 & $\mathrm{r}$ & 2730 & & Lowland meadows & \\
\hline Athyrium distentifolium & & & 1 & 1 & $\mathrm{r}$ & 2230 & 2700 & Shrubs and forests & Stones and/or gravel \\
\hline Poa supina / P. annua / P. badensis & & & 1 & $*$ & $\mathrm{r}$ & 2600 & 2720 & Others & Track \\
\hline Diphasiastrum alpinum & & & 1 & $*$ & $\mathrm{r} !$ & 2630 & 2700 & Lowland meadows & Grassland \\
\hline Ribes petraeum & & & 1 & $*$ & $\mathrm{r} !$ & 2450 & 2530 & Shrubs and forests & Heathland \\
\hline Salix helvetica & & & 1 & 1 & $r !$ & 2500 & 2510 & Shrubs and forests & Stones and/or gravel \\
\hline Gymnocarpium dryopteris & & & & 1 & $\mathrm{r} !$ & 2570 & 2540 & Shrubs and forests & Stones and/or gravel \\
\hline cf Aster bellidiastrum & & & & & $\mathrm{r} !$ & 2600 & 2540 & Alpine grasslands & \\
\hline Gentiana verna & & & & & $\mathrm{r} !$ & 2900 & 2560 & Alpine grasslands & Grassland \\
\hline Leontodon cf autumnalis & & & & & $\mathrm{r} !$ & 2320 & 2720 & Lowland meadows & Track \\
\hline Pulsatilla alpina s.l. & & & & & $\mathrm{r} !$ & 2730 & 2710 & Lowland meadows & Grassland \\
\hline Arctostaphylos uva-ursi & & & & & $\mathrm{r} !$ & 2550 & 2500 & Shrubs and forests & Stones and/or gravel \\
\hline Dryopteris filix-mas & & & & & $\mathrm{r} !$ & 2540 & 2540 & Shrubs and forests & Stones and/or gravel \\
\hline Larix decidua & & & & & $\mathrm{r} !$ & 2660 & 2510 & Shrubs and forests & Stones and/or gravel \\
\hline Dryopteris cf dilatata & & & & & $\mathrm{r} !$ & 2260 & 2520 & Shrubs and forests & Stones and/or gravel \\
\hline Festuca rubra aggr. & & & & & $\mathrm{r} !$ & 2650 & 2540 & Others & Grassland \\
\hline
\end{tabular}

The sociology of original and recent plant species differed significantly (Tab. 3). The newly arrived species were associated in similar proportions with forests (Vaccinio-Piceetea, Erico-Pinetea, Querco-Fagetea), alpine grasslands (Salicetea herbaceae, Juncetea trifidi, Seslerietea albicantis, Carici rupestri-Kobresietea, Loiseleurio-Vaccinietalia, Poion alpinae) or montane and/or subalpine grasslands (Nardo-Callunetea, Molinio-Arrhenatheretea) (Tab. 2; Fig. 4). Altogether, forests and montane-subalpine grassland species represented $23 \%$ of the 1906 floristic composition but $45 \%$ of the new species. By contrast, alpine grassland and rock/scree species (Asplenietea trichomanis, Thlaspietea rotundifolii, Sedo-Scleranthetea) comprised only $36 \%$ of the new species, while they comprised $70 \%$ of the 1906 composition (Fig. 4). 
Table 3. $\mathrm{P}$ values for the comparisons of biological traits between the species present in the 1906-inventory on Isla Persa and those that arrived later are obtained by $\chi^{2}$-tests (see Methods for the description of traits).

\begin{tabular}{lc}
\hline Biological trait & $\mathrm{p}$-value \\
\hline Soil texture & 0.134 \\
Soil humus content & 0.130 \\
Soil nutrients content & 0.257 \\
Temperature & $<\mathbf{0 . 0 0 0 1}$ \\
Sociology & $\mathbf{0 . 0 0 9}$ \\
Growth form & 0.243 \\
Reproduction type & 0.288 \\
Fertilization type & $\mathbf{0 . 0 0 6}$ \\
Fertilization type (without ferns) & 0.351 \\
Diaspore weight & $\mathbf{0 . 0 1 7}$ \\
Diaspore weight (without ferns) & 0.497 \\
Dispersal distance & 0.240 \\
\hline
\end{tabular}

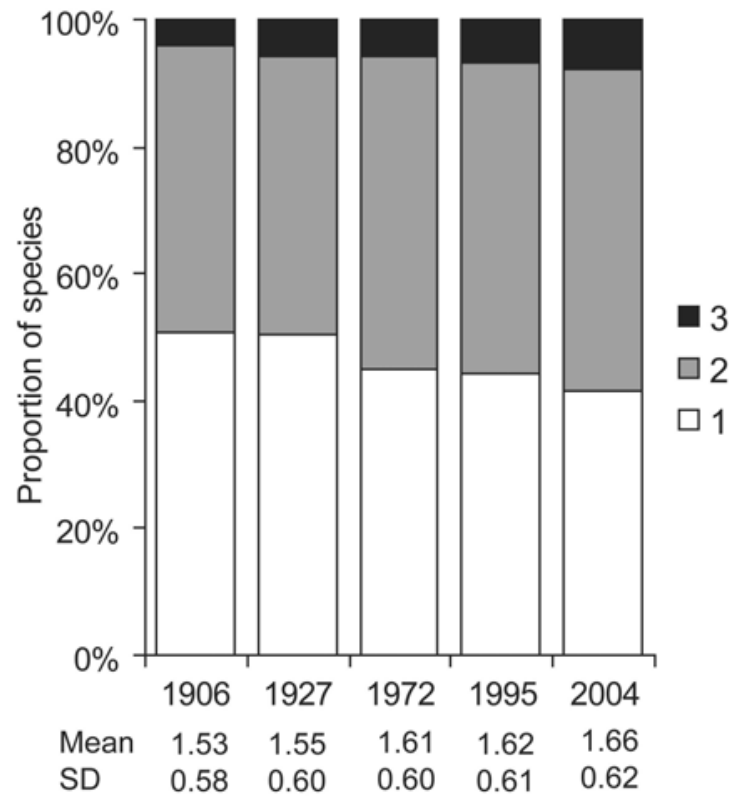

Fig. 3. Proportion of species corresponding to the different temperature indicator values following Landolt (1977) in the floristic inventories on Isla Persa: 1 species typically distributed in alpine and nival belts, 2 subalpine species, 3 montane or indifferent species. Mean and standard deviation (SD) for the complete inventories are given for the individual years.

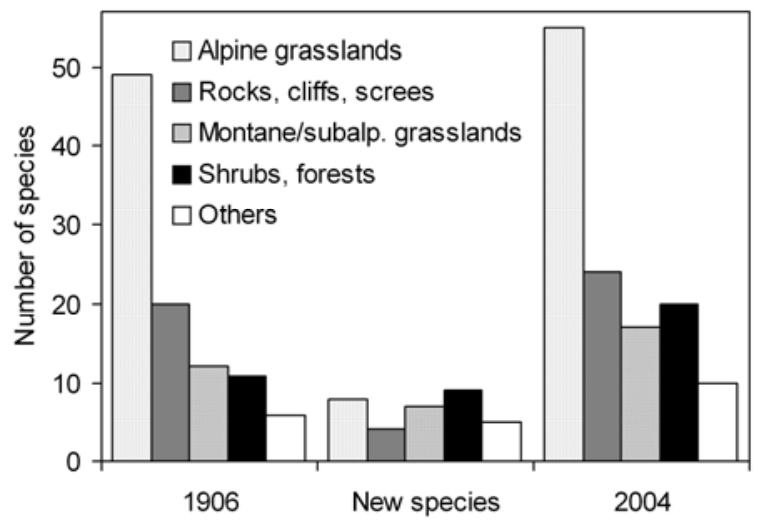

Fig. 4. Plant sociological preferences (Ellenberg et al. 1991; Aeschimann et al. 2004) of the 98 species already present in 1906, the 31 species that arrived later, and of the 126 species present in 2004 (for details and relative values see text). 
The growth forms were similarly distributed (Tab. 3), with a large dominance of hemicryptophytes in both groups, although a higher proportion of non-graminoid hemicryptophytes was observed in the original inventory (App. 2 in supplementary archives). The reproduction type showed no difference between inventories, with 74 and $72 \%$ of species able to reproduce sexually and clonally in the two groups (Tab. 3). The fertilization type was significantly different because of a higher proportion of ferns among the recently arrived species $(24.2 \%$ compared to $4.1 \%$ among the 1906-species). When only the phanerogames were considered, there was not a significant difference between fertilization types (Tab. 3), with approximately $66 \%$ and $68 \%$, respectively, of either obligatory or non-obligatory entomophilous species. Similarly, diaspore weight was significantly different when all the species were considered, with a higher proportion of very light diaspores among colonizing species (Fig. 5) but no significant difference when only phanerogams were considered (Tab. 3). Finally, no difference was found in dispersal vectors, with 83 and $85 \%$ of the seeds dispersed by wind or without special device for dispersal and $26-27 \%$ of zoochorous dispersal, including unintentional endozoochory by consumption with grass (results not shown). Dispersal distance type showed no significant difference between species present in the 1906-inventory and species that arrived later (Tab. 3; App. 3 in supplementary material).

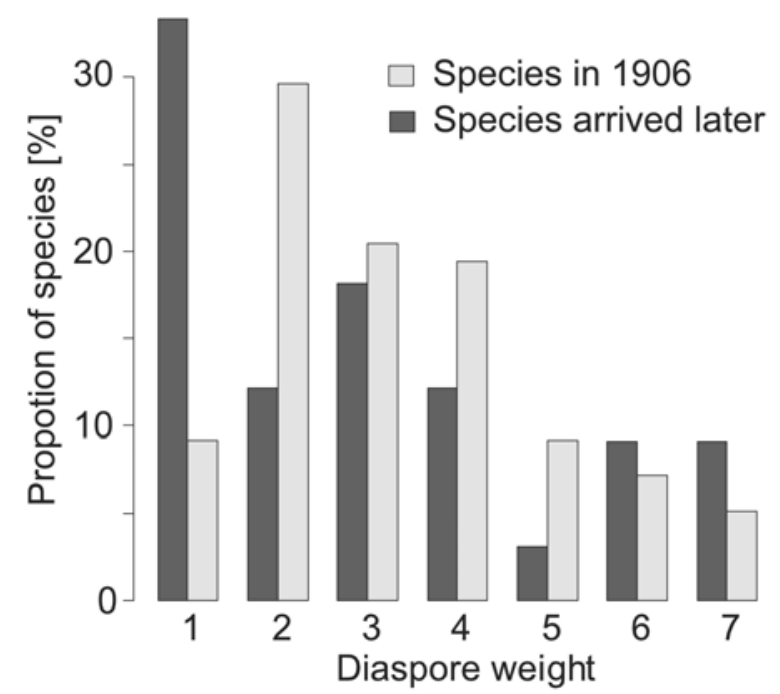

Fig. 5. Distribution of diaspore weight for species present in the 1906-inventory on Isla Persa and the 31 that arrived later (see Methods for the seven types).

\section{Discussion}

Data reliability

The comparison of this type of floristic data in large areas is always confronted with the problem of completeness and reliability. Clearly, the prospecting effort is variable between the different inventories (Tab. 1). For instance, we do not know how much time Rübel spent for the first inventory in 1906, but it was probably less than the 27 day equivalent that Braun-Blanquet invested with his students in 1927 (Flütsch et al. 1930). Previous studies have often shown that botanical inventories are rarely exhaustive, even in very small areas (e.g. Lepš \& Hadincová 1992; Klimeš et al. 2001; Kercher et al. 2003; Archaux et al. 2006; Vittoz \& Guisan 2007). Two easy ways to improve data and interpretation exist: working in groups increases the reliability of species lists (Klimeš et al. 2001; Vittoz \& Guisan 2007) and estimation of cover helps to cautiously interpret the results for new but rare species (Lepš \& Hadincová 1992; Kercher et al. 2003; Vittoz \& Guisan 2007). On Isla Persa, most inventories were completed by teams (Tab. 1) but cover estimates in the earlier inventories would have allowed more detailed analyses of abundance changes (e.g., Vittoz et al. 2006).

\section{Biodiversity increase and climate change}

Climate warming, although less pronounced in this region compared to other Swiss regions (Fig. 2), is probably responsible for the observed species increase on the Isla Persa. This is consistent 
with newly arrived plant species showing higher temperature requirements (Fig. 3) and observations of particular species at higher altitudes in 2004 than in 1906. The same trend is also observed on many surrounding summits (Braun-Blanquet 1957; Hofer 1992; Grabherr et al. 2001; Camenisch 2002; Burga et al. 2004; Walther et al. 2005a) or in other alpine regions (Grabherr et al. 2001; Vittoz et al. 2006; Parolo \& Rossi in press). Recent re-observations at an alpine-nival ecotone of the central Alps showed an increase in cover of high-alpine species and a concurrent decline of all subnival to nival species, suggesting a range shift of mountain plants (Pauli et al. 2007).

Higher temperatures allow more sensitive plants to colonize the nunatak. These newly arrived species indicate a slow shift of the vegetation from mainly alpine meadows and rocky vegetation to conditions typical of the lower alpine belt, or even the subalpine belt. Although rocky sites and screes are still dominant on the nunatak, most of the new species are indeed associated with grasslands or wooded areas (Fig. 3). The clear increase of Vaccinium myrtillus, a typical species of subalpine forests or lower alpine dwarf shrubs heath, indicates a possible belt shift. This development correlates with the results of Wahren et al. (2005) in warming experiments on Arctic tundra vegetation showing the increasing size and cover of small shrubs. Similar altitudinal/latitudinal belt shifts were observed in other regions as well, like the expansion of the treeline ecotone (e.g. Kullman 1986; Taylor 1995; Peñuelas \& Boada 2003; Camarero and Gutiérrez, 2004; Vittoz et al. in press) or the colonization of shrubs in the Arctic tundra (Sturm et al. 2001) and in the boreal mountains (Klanderud \& Birks 2003). The arrival of Salix helvetica, Ribes petraeum and especially the first occurrence of Larix decidua, on Isla Persa is perhaps an early indication of the upward expansion of the treeline. This last species is, at present, limited to one individual that colonized the nunatak no earlier than 1994 (based on the annual increments of the shoots).

Another indication of warmer conditions on the nunatak is the observed higher fitness of Epilobium angustifolium. Rübel (1912) mentioned its sterile occurrence at the foot of the 'island' (2530 $\mathrm{m}$ a.s.1). The same species was missing in the inventory of Flütsch et al. (1930), whereas De Haas (1973) reported a mainly vegetative spreading species. In 2003, the population was found at the same location in full flower (for the advance of the same species in the Arctic see Kullman 2003). The shift from mainly vegetative to fertile populations of Epilobium angustifolium underlines the possibility for species with lower core distribution to colonize and become established at their upper range limit.

Other factors are certainly partially responsible for the observed vegetation changes on Isla Persa: (i) Some new species most likely arrived with a re-colonisation process after the climate change that followed the Little Ice Age (Kammer et al. 2007). Species became extinct during this cold period and re-colonised Isla Persa, much like surrounding summits, in warmer conditions. This process was probably slowed by the low dispersal ability of many species and is now being accelerated by anthropogenic warming (Walther et al. 2005a). (ii) Another portion of the new species may correspond to the continuous colonization observed on every island (MacArthur \& Wilson 1967). With 49 alpine grassland species in 1906, the species pool on Isla Persa was not saturated, since it is estimated that about 100 potential species of acidophilous alpine grasslands exist in the Eastern Swiss Alps (calculated by crossing data from Landolt 1977, Ellenberg et al. 1991, Moser et al. 2002 and Aeschimann et al. 2004). Similarly, the 20 species on rocks, cliffs or screes in 1906 represented less than half of the pool of 54 potential species. Respectively, the 8 and 4 new species associated with these environments (Tab. 2; Fig. 4), some very common in alpine conditions (e.g., Soldanella alpina in alpine grasslands and Cerastium uniflorum in screes) can be considered as colonizations independent of climate change. (iii) Primary succession in the Rübel area cannot alone be responsible for the increase in species numbers on the nunatak, since it has been ice-free for many thousands of years. It was not covered by ice in 1850 and glaciers in the Alps did not exceed their 1850 extent throughout the Holocene (Maisch et al. 1999). Hence, a large part of the local vegetation must have been at the succession climax for a long time. However, a primary succession is possible on some of the rocky areas, with potentially increasing biodiversity, but mostly with already present species. (iv) Interannual fluctuations are sometimes responsible for vegetation changes (van der Maarel 1996). However, the different inventories of the Rübel area showed a continuous increase in species richness and, furthermore, such fluctuations have low amplitudes at these altitudes. Finally, (v) the glacier barrier strongly limits cattle grazing on Isla Persa and a vegetation change after pasture abandonment is very improbable. Only the hikers' influence seems to have contributed slightly to the enrichment, 
responsible for the arrival of a few species, like Poa supina or Leontodon cf. autumnalis, which were found on the most trampled spot - all the other newcomer species were recorded well off the track.

\section{Biological traits}

Apart from temperature and sociology of the species (see above), fertilization type and diaspore weight were the only biological traits considered that showed a significant difference between originally established species (1906) and new species (Tab. 3). For both traits, however, the high proportion of Pteridophytes (26\% of the new species but only 4\% in the 1906 inventory) is responsible for this difference: they were classified separately for the fertilization type and, with spores, they all have very light diaspores $(<0.05 \mathrm{mg}$ category). Similarly, four fern species were classified by Parolo \& Rossi (in press) as fast migrants because of their important altitudinal shift between 1959 and 2005. It is very probable that their small spores give them an advantage for longdistance dispersal because of a high efficiency of wind as a dispersal vector. A high proportion of pteridophytes were found as well on a new volcanic island whose situation strongly favored anemochory (Thornton et al. 2001). However, pteridophyte establishment in this alpine environment could be more difficult because the small size and dependence of photosynthesis of prothalli (fern gametophytes) which make them little competitive in grasslands (Greer 1993). This may perhaps explain why almost all new pteridophytes are established on mineral soils (stones and/or gravel), even though four species normally grow in forest soils. The number of individuals and species is too low to conclude if the colonization rate of pteridophytes in alpine environments under climate change is generally higher than for other vascular plant species.

The similarity of other biological traits between original species and newly arrived ones show that changes in vegetation structure were not yet important enough to significantly influence the trait pattern. Alpine conditions governed the observed plant traits in both groups: the dominance of hemicryptophytes is typical of alpine vegetation (Illa et al. 2006; Körner 2003), as well as a majority of plants with possible clonal reproduction (Stöcklin 1992; Illa et al. 2006) and the dominance of insect fertilization (Körner 2003). The seed weight, which shows a comparable majority of seeds $<1$ $\mathrm{mg}$, as in sub-arctic grasslands (Welling et al. 2005), seems not to be related to altitude, with mean weight similar between alpine and lowland grasslands (Körner 1999). Finally, the importance of wind as dispersal vector (including for small seeds without special device; Willson et al. 1990) is typical of alpine plant communities, more generally of grasslands and vegetation with an open structure (Willson et al. 1990; Stöcklin \& Bäumler 1996; Ozinga et al. 2004), typical of island colonization (Lloret et al. 2005). This similarity strongly limits the opportunities to detect differences in dispersal vectors and distances between established plants in 1906 and newcomers.

\section{Importance of the biodiversity increase}

Compared to other similar studies, the increase in species richness on Isla Persa is relatively small. The increase of $29 \%$ for recorded vascular plant species in the course of one century recorded for the Isla Persa is clearly below the values for most of the surrounding mountain summits. Of the eleven inventoried summits in the Bernina region (Walther et al. 2005a; Vittoz unpublished data), eight showed a stronger increase of richness $(58-336 \%$, mean $=131 \%)$. However, all these mountain summits are at a higher altitude and are dominated by rock surfaces, with very limited areas of alpine grassland. Various reasons may explain this comparatively small change on the nunatak. (i) Physical barriers created by the surrounding glaciers limited the colonization by plants, as was hypothesized for the observed stable richness (since 1937) of the Piz Linard (3411 m) (Pauli et al. 2001). Conversely, most of the inventoried summits in the Bernina region have gradually changing conditions, which allows a progressive migration of plants. (ii) The species richness on Isla Persa was about half of the species pool for alpine grasslands and rock areas, limiting the number of potential newcomers. (iii) Subalpine species arriving in well-developed alpine grasslands are not free to colonize all potentially suitable sites because most of them are already occupied, or, at the least, the newcomers need more time to increase their abundance under the still prevailing cold alpine conditions. The increase of Vaccinium myrtillus supports this hypothesis as mature plants of this taxon are taller than those of most other alpine species and hence less inhibited by competition. (iv) Surrounding glaciers bring about a colder microclimate than usually exists for other localities at similar altitudes. Unfortunately, comparable floristic data at similar altitudes are lacking, at least assessments covering a time span of a 
century. Hence, it is impossible to conclude if the Isla Persa species enrichment should have been expected to be higher than observed, as suggested by Grabherr et al. (1994) who showed increasing enrichment for decreasing altitudes within upper alpine and nival belts.

The nunatak of Isla Persa in the Eastern Swiss Alps is probably one of the rare available sites at which vegetation changes in the alpine belt can be assessed over the course of $20^{\text {th }}$ century. The observed changes were less pronounced than expected based the results of similar studies for surrounding mountain summits, and while new species colonized the nunatak, most of them are still rare. However, the sum of the evidence presented here indicates a shift towards a vegetation of previously restricted lower altitudinal belts and thus, a trend indicating warmer local growth conditions. The conspicuous increase of Vaccinium myrtillus and the new presence of shrub and tree species underline this conclusion. Among the new species, ferns were particularly important, which can be due to a high dispersal potential brought about by their lightweight spores. But altogether, the pool of potential newcomers is still too strongly restricted by the alpine climate to have biological traits distinct from those of the species in the 1906-inventory. Additional data obtained in the future should help to gain a better understanding of processes influencing species composition in alpine grasslands and dwarf shrub heaths in a warmer world.

\section{Acknowledgements}

This research has been supported by the Federal Office for the Environment FOEN (Switzerland), the Fondation Herbette (University of Lausanne) for P. Vittoz, by the DFG (German Research Foundation) within the project WA 1523/6-1 for G.-R. Walther and by the EC within the FP 6 Integrated Project "ALARM" (GOCE-CT-2003-5006675) for J. Bodin. We are grateful to J. Barkowski, S. Beißner, S. Berger, E. Frei \& S. Jutzeler for their participation in the field work and to J.-P. Müller (Chur/CH) and the staff of the library of St. Moritz for providing historic literature. Special thanks go to R. Reinalter (Brail/CH) for his support in the identification of plant species and to R.H. Økland, H. Pauli and an anonymous referee for their useful comments on an earlier version of the manuscript.

\section{References}

Aeschimann, D., Lauber, K., Moser, D.M. \& Theurillat, J.-P. 2004. Flora alpina. Belin, 3 vol.

Archaux, F., Gosselin, F., Bergès, L. \& Chevalier, R. 2006. Effects of sampling time, species richness and observer on the exhaustiveness of plant censuses. J. Veg. Sci. 17: 299-306.

Bader, S. \& Bantle, H. 2004. Das Schweizer Klima im Trend: Temperatur- und Niederschlagsentwicklung 1864-2001. Veröffentlichungen 68. MeteoSchweiz, Zürich.

Braun-Blanquet, J. 1957. Ein Jahrhundert Florenwandel am Piz Linard (3414 m). Bull. Jardin Bot. Bruxelles, vol. jubil. W. Robyns: 221-232

Büchi, H. 1994. Der variskische Magmatismus in der östlichen Bernina (Graubünden, Schweiz). Schweiz. Mineral. Petrogr. Mitt. 74: 359-371.

Burga, C.A. 1999. Vegetation development on the glacier forefield Morteratsch (Switzerland). Appl. Veg. Sci. 2: 17-24.

Burga, C.A., Walther, G.R. \& Beissner, S. 2004. Florenwandel in der alpinen Stufe des Berninagebiets - ein Klimasignal. Ber. d. Reinh.-Tüxen-Ges. 16: 57-66.

Camarero, J.J., \& Gutiérrez, E., 2004. Pace and pattern of recent treeline dynamics: response of ecotones to climatic variability in the Spanish Pyrenees. Climatic Change 63: 181-200.

Camenisch, M. 2002. Veränderungen der Gipfelflora im Bereich des Schweizerischen Nationalparks: Ein Vergleich über die letzten 80 Jahre. Jahresber. Naturf. Ges. Graubündens 111: 27-37

De Haas, J.H. 1973. The vegetation of Isla Persa (Bernina, Switzerland) - a standard of climatic changes? Field reports of the Netherlands centre for alpine biological research, Utrecht, NL. 
Dirnböck, T., Dullinger, S. \& Grabherr, G. 2003. A regional impact assessment of climate and landuse change on alpine vegetation. J. Biogeogr. 30: 401-417.

Dobbertin, M., Hilker, N., Rebetez, M. Zimmermann, N.E., Wohlgemuth, T. \& Rigling, A. 2005. The upward shift of pine mistletoe (Viscum album ssp. austriacum) in Switzerland. The result of climate warming? Int. J. Biometeorol. 50: 40-47.

Ellenberg, H., Weber, H.E., Düll, R., Wirtz, V., Werner, W. \& Paulissen, D. 1991. Zeigerwerte von Pflanzen in Mitteleuropa. Scripta Geobotanica 18, Goltze KG, Göttingen.

Flütsch, P. 1930. Über die Pflanzengesellschaften der alpinen Stufe des Berninagebietes. Jahresber. Naturf. Ges. Graubündens 68: 37-88.

Gottfried, M., Pauli, H. \& Grabherr, G. 1998. Prediction of vegetation patterns at the limits of plant life: a new view of the alpine-nival ecotone. Arctic Alpine Res. 30: 207-221.

Grabherr, G., Gottfried, M. \& Pauli, H. 2001. Long term monitoring of mountain peaks in the Alps. In: Burga, C. \& Kratochwil, A. (eds). Biomonitoring: general and applied aspects on regional and global scales. Dordrecht, Kluwer.

Grabherr, G., Gottfried, M. \& Pauli, H. 1994. Climate effects on mountain plants. Nature 369: 448.

Grabherr, G., Gottfried, M., Gruber, A. \& Pauli, H. 1995. Patterns and current changes in alpine plant diversity. In: Chapin III, F.S. \& Körner, C. (eds). Arctic and alpine Biodiversity. Ecological Studies 113. Springer, Berlin.

Greer, G.K. 1993. The influence of soil topography and spore-rain density on gender expression in gametophyte populations of the homosporous fern Aspidotis densa. Am. Fern J. 83: 54-59.

Guisan, A. \& Theurillat, J.-P. 2000. Assessing alpine plant vulnerability to climate change: a modeling perspective. Integrated Assessment 1: 307-320.

Hofer, H.R. 1992. Veränderungen in der Vegetation von 14 Gipfeln des Berninagebietes zwischen 1905 und 1985. Ber. Geobot. Inst. Eidgenöss. Tech. Hochsch. Stift. Rübel Zür. 58: 39-54.

Illa, E., Carrillo, E. \& Ninot, J.M. 2006. Patterns of plant traits in Pyrenean alpine vegetation. Flora 201: 528-546.

Kammer, P.M., Schöb, C. \& Choler, P. 2007. Increasing species richness on mountain summits: upward migration due to anthropogenic climate change or re-colonisation? J. Veg. Sci. 18: 301306.

Kercher, S.M., Frieswyk, C.B. \& Zedler, J.B. 2003. Effects of sampling teams and estimation methods on the assessment of plant cover. J. Veg. Sci. 14: 899-206.

Klanderud, K. \& Birks, H.J.B. 2003. Recent increases in species richness and shifts in altitudinal distributions of Norwegian mountain plants. Holocene 13: 1-6.

Klimeš, L., Dančák, M., Hájek, M., Jongepierová, I. \& Kučera, T. 2001. Scale-dependent biases of species counts in a grassland. J. Veg. Sci. 12: 699-704.

Klotz, S., Ingolf, K. \& Durka, W. 2002. BIOLFOR - Eine Datenbank mit biologisch-ökologishen Merkmalen zur Flora von Deutschland. Schriftenreihe für Vegetationskunde 38, Bundesamt für Naturschutz, Bonn.

Körner, C. 2003. Alpine plant life. 2nd ed. Springer, Berlin.

Kudernatsch, T., 2005: Auswirkungen der globalen Erwärmung auf die Vegetation alpiner KalkMagerrasen im Nationalpark Berchtesgaden. Doctoral-Thesis, Department of Ecology, Technical University of Munich.

Kullman, L., 1986: Late Holocen reproductional patterns of Pinus sylvestris and Picea abies at the forest limit in central Sweden. Can. J. Bot. 64: 1682-1690.

Kullmann, L., 2003: Förändringar i fjällens växtvärld - effekter av varmare klimat. [Changes in alpine plant cover - effects of climate warming.] Svensk Bot. Tidskr. 97: 210-221.

Landolt, E. 1977. Ökologische Zeigerwerte zur Schweizer Flora. Veröff. Geobot. Inst. ETH Stiftung Rübel Zürich 64: 1-208. 
Lechner, E. 1858. Piz Languard und die Bernina-Gruppe bei Pontresina. Wilhelm Engelmann, Leipzig.

Lepš, J. \& Hadincová, V. 1992. How reliable are our vegetation analyses? J. Veg. Sci. 3: 119-124.

Lloret, F., Medail, F., Brundu, G., Camarda, I., Moragues, E., Rita, J., Lambdon, P. \& Hulme, P. E. 2005. Species attributes and invasion success by alien plants on Mediterranean islands. J. Ecol. 93: 512-520.

MacArthur, R.H. \& Wilson E.O. 1967. The theory of island biogeography. Princeton University Press, Princeton.

Maisch, M., Burga, C.A. \& Fitze, P. 1999. Lebendiges Gletschervorfeld. Führer und Begleitbuch zum Gletscherlehrpfad Morteratsch. $2^{\text {nd }}$ Ed. Engadin Press, Samedan.

Moiseev, P.A. \& Shiyatov, S.G. 2003. Vegetation dynamics at the treeline ecotone in the Ural highlands, Russia. In: Nagy, L., Grabherr, G., Körner, C. \& Thompson, D.B.A. (eds.). Alpine biodiversity in Europe - A Europe-wide assessment of biological richness and change. Ecological Studies, Springer, Berlin.

Moser, D.M., Gygax, A., Bäumler, B., Wyler, N. \& Palese R. 2002. Liste Rouge des fougères et plantes à fleur menacées de Suisse. Série OFEFP "L'environnement pratique". Office fédéral de l'environnement, des forêts et du paysage, Berne.

Müller-Schneider, P. 1986. Verbreitungsbiologie der Blütenpflanzen Graubündens. Veröff. Geobot. Inst. ETH Stiftung Rübel Zürich 85: 1-263.

Ozinga, W.A., Bekker, R.M., Schaminée, J.H. \& van Groenendael, J.M. 2004. Dispersal potential in plant communities depends on environmental conditions. J. Ecol. 92: 767-777.

Parolo, G. \& Rossi, G. In press. Upward migration of vascular plants following a climate warming trend in the Alps. Basic Appl. Ecol. doi:10.1016/j.baae.2007.01.005.

Paul, F., Kääb, A., Maisch, M., Kellenberger, T. \& Haeberli, W. 2004. Rapid disintegration of Alpine glaciers observed with satellite data. Geophys. Res. Lett. 31. L21402, doi:10.1029/2004GL020816

Pauli, H., Gottfried, M., Grabherr, G. 2001. High summits of the Alps in a changing climate. In: Walther, G.-R., Burga, C.A. \& Edwards, P.J. (eds). 'Fingerprints' of Climate Change - Adapted behaviour and shifting species ranges. Kluwer Academic/Plenum Publ., New York.

Pauli, H., Gottfried, M., Reiter, K., Klettner, C., \& Grabherr, G. 2007. Signals of range expansions and contractions of vascular plants in the high Alps: Observations (1994-2004) at the GLORIA master site Schrankogel, Tyrol, Austria. Global Change Biol. 13: 147-156.

Peñuelas, J. \& Boada, M. 2003. A global change-induced biome shift in the Montseny mountains (NE Spain). Global Change Biol. 9: 131-140.

Pignatti, S. 2005. Valory di bioindicazione delle piante vascolari della flora d'Italia. Braun-Blanquetia 39: 1-97.

Rebetez, M. \& Reinhard, M. In press. Monthly air temperature trends in Switzerland 1901-2000 and 1975-2004. Theor. Appl. Climat. DOI 10.1007/s00704-007-0296-2.

Rübel, E. 1912. Pflanzengeographische Monographie des Berninagebietes. Engelmann, Leipzig.

Stöcklin, J. 1992. Umwelt, Morphology und Wachstumsmuster klonaler Pflanzen - eine Übersicht. Bot. Helv. 102: 3-21.

Stöcklin, J. \& Bäumler, E. 1996. Seed rain, seedling establishment and clonal growth strategies on a glacier foreland. J. Veg. Sci. 7: 45-56.

Sturm, M., Racine, C. \& Tape, K. 2001. Climate change - Increasing shrub abundance in the Arctic. Nature 411: 546-547.

Taylor, A.H., 1995: Forest expansion and climate change in the mountain hemlock (Tsuga mertensiana) zone, Lassen Volcanic National Park, California, U.S.A. Arctic Alpine Res. 27: 207-216. 
Thornton, I.W.B., Cook, S., Edwards, J.S., Harrison, R.D., Schipper, C., Shanahan, M., Singadan, R. \& Yamuna, R. 2001. Colonization of an island volcano, Long Island, Papua New Guinea, and an emergent island, Motmot, in its caldera lake. VII. Overview and discussion. J. Biogeogr. 28: 1389-1408.

Ungricht, S. 1995. Die Flora der Gletscherinsel Isla Persa (Bernina, Graubünden) - Ein Indikator für eine Klimaerwärmung? Seminar Thesis, ETH Zürich.

van der Maarel, E. 1996. Pattern and process in the plant community: fifty years after A.S. Watt. $J$. Veg. Sci. 7: 19-28.

Vittoz, P. \& Engler, R. In press. Seed dispersal distances: a typology based on dispersal modes and plant traits. Bot. Helv.

Vittoz, P. \& Guisan, A. 2007. How reliable is the monitoring of permanent vegetation plots? A test with multiple observers. J. Veg. Sci.18: 413-422.

Vittoz, P., Jutzeler, S. \& Guisan, A. 2006. Flore alpine et réchauffement climatique: observation de trois sommets valaisans à travers le $20^{\text {ème }}$ siècle. Bull. Murithienne 123/2005: 49-59.

Vittoz, P., Rulence, B., Largey, T. \& Freléchoux, F. In press. Effects of climate and land-use change on the establishment and growth of cembran pine (Pinus cembra L.) over the altitudinal treeline ecotone in the Central Swiss Alps. Arctic Antarctic Alpine Res.

Wahren, C.-H.A., Walker, M.D. \& Bret-Harte, M.S. 2005. Vegetation responses in Alaskan arctic tundra after 8 years of a summer warming and winter snow manipulation experiment. Global Change Biol. 11: 537-552.

Walther, G.-R. 2004. Plants in a warmer world. Perspect. Plant Ecol. Evol. Syst. 6: 169-185.

Walther, G.-R. Beißner, S. \& Burga, C.-A. 2005a. Trends in the upward shift of alpine plants. J. Veg. Sci. 16: $541-548$

Walther, G.-R., Berger, S. \& Sykes, M.T. 2005b. An ecological „footprint“" of climate change. P. Roy. Soc. B-Biol. Sci. 272: 1427-1432.

Welling, P., Tolvanen, A. \& Laine, K. 2005. Plant traits: Their role in the regeneration of alpine plant communities in sub-arctic Finland. J. Veg. Sci. 16: 183-190.

Willson, M.F., Rice, B.L. \& Westoby, M. 1990. Seed dispersal spectra: a comparison of temperate plant communities. J. Veg. Sci. 1: 547-562. 


\section{Supplementary archives}

App. 1. Comparative plant inventory on Isla Persa (Swiss Alps). 1 species present without abundance estimation; * species probably overlooked because present in a previous and following inventory; $\mathbf{r}$ ! very rare; $\mathbf{r}$ rare; $\mathbf{s}$ scattered; c common; $\mathbf{d}$ dominant; precision given if locally different (for example s-lc for scattered but locally common).

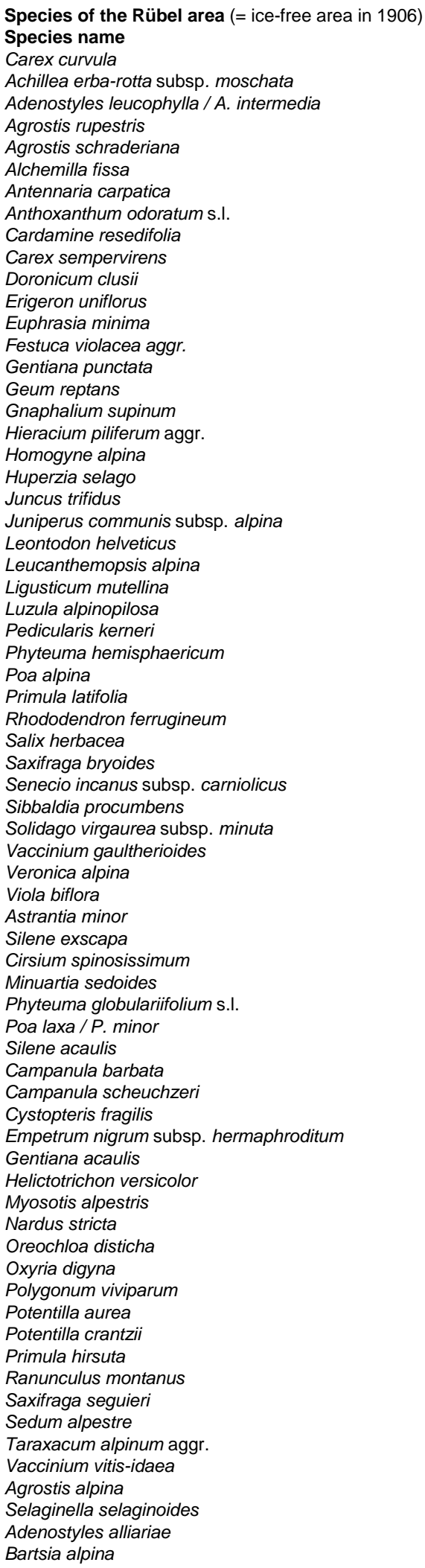

\begin{tabular}{|c|c|c|c|c|}
\hline & & Year & & \\
\hline 1906 & 1927 & 1972 & 1995 & $2003 / 4$ \\
\hline 1 & 1 & 1 & 1 & c-ld \\
\hline 1 & 1 & 1 & 1 & C \\
\hline 1 & 1 & 1 & 1 & C \\
\hline 1 & 1 & 1 & 1 & C \\
\hline 1 & 1 & 1 & 1 & C \\
\hline 1 & 1 & 1 & 1 & C \\
\hline 1 & 1 & 1 & 1 & C \\
\hline 1 & 1 & 1 & 1 & C \\
\hline 1 & 1 & 1 & 1 & C \\
\hline 1 & 1 & 1 & 1 & C \\
\hline 1 & 1 & 1 & 1 & C \\
\hline 1 & 1 & 1 & 1 & C \\
\hline 1 & 1 & 1 & 1 & C \\
\hline 1 & 1 & 1 & 1 & C \\
\hline 1 & 1 & 1 & 1 & C \\
\hline 1 & 1 & 1 & 1 & C \\
\hline 1 & 1 & 1 & 1 & C \\
\hline 1 & 1 & 1 & 1 & C \\
\hline 1 & 1 & 1 & 1 & C \\
\hline 1 & 1 & 1 & 1 & C \\
\hline 1 & 1 & 1 & 1 & C \\
\hline 1 & 1 & 1 & 1 & C \\
\hline 1 & 1 & 1 & 1 & C \\
\hline 1 & 1 & 1 & 1 & c \\
\hline 1 & 1 & 1 & 1 & C \\
\hline 1 & 1 & 1 & 1 & C \\
\hline 1 & 1 & 1 & 1 & C \\
\hline 1 & 1 & 1 & 1 & C \\
\hline 1 & 1 & 1 & 1 & C \\
\hline 1 & 1 & 1 & 1 & C \\
\hline 1 & 1 & 1 & 1 & C \\
\hline 1 & 1 & 1 & 1 & C \\
\hline 1 & 1 & 1 & 1 & C \\
\hline 1 & 1 & 1 & 1 & C \\
\hline 1 & 1 & 1 & 1 & $\mathrm{C}$ \\
\hline 1 & 1 & 1 & 1 & C \\
\hline 1 & 1 & 1 & 1 & C \\
\hline 1 & 1 & 1 & 1 & c \\
\hline 1 & 1 & 1 & 1 & C \\
\hline 1 & 1 & 1 & * & C \\
\hline 1 & 1 & 1 & * & C \\
\hline 1 & 1 & 1 & 1 & s-lc \\
\hline 1 & 1 & 1 & 1 & s-lc \\
\hline 1 & 1 & 1 & 1 & s-lc \\
\hline 1 & 1 & 1 & 1 & S-lc \\
\hline 1 & * & 1 & 1 & S-lc \\
\hline 1 & 1 & 1 & 1 & $\mathrm{~s}$ \\
\hline 1 & 1 & 1 & 1 & $\mathrm{~s}$ \\
\hline 1 & 1 & 1 & 1 & $\mathrm{~s}$ \\
\hline 1 & 1 & 1 & 1 & $\mathrm{~s}$ \\
\hline 1 & 1 & 1 & 1 & $\mathrm{~S}$ \\
\hline 1 & 1 & 1 & 1 & $\mathrm{~s}$ \\
\hline 1 & 1 & 1 & 1 & $S$ \\
\hline 1 & 1 & 1 & 1 & $\mathrm{~s}$ \\
\hline 1 & 1 & 1 & 1 & $\mathrm{~s}$ \\
\hline 1 & 1 & 1 & 1 & $\mathrm{~s}$ \\
\hline 1 & 1 & 1 & 1 & $\mathrm{~s}$ \\
\hline 1 & 1 & 1 & 1 & $\mathrm{~s}$ \\
\hline 1 & 1 & 1 & 1 & $\mathrm{~s}$ \\
\hline 1 & 1 & 1 & 1 & $\mathrm{~s}$ \\
\hline 1 & 1 & 1 & 1 & $\mathrm{~s}$ \\
\hline 1 & 1 & 1 & 1 & $\mathrm{~s}$ \\
\hline 1 & 1 & 1 & 1 & $\mathrm{~s}$ \\
\hline 1 & 1 & 1 & 1 & $\mathrm{~s}$ \\
\hline 1 & * & 1 & 1 & $\mathrm{~s}$ \\
\hline 1 & 1 & 1 & * & $\mathrm{s}$ \\
\hline 1 & * & 1 & * & $\mathrm{s}$ \\
\hline 1 & 1 & 1 & 1 & $r-I c$ \\
\hline 1 & 1 & 1 & 1 & $r-I C$ \\
\hline
\end{tabular}




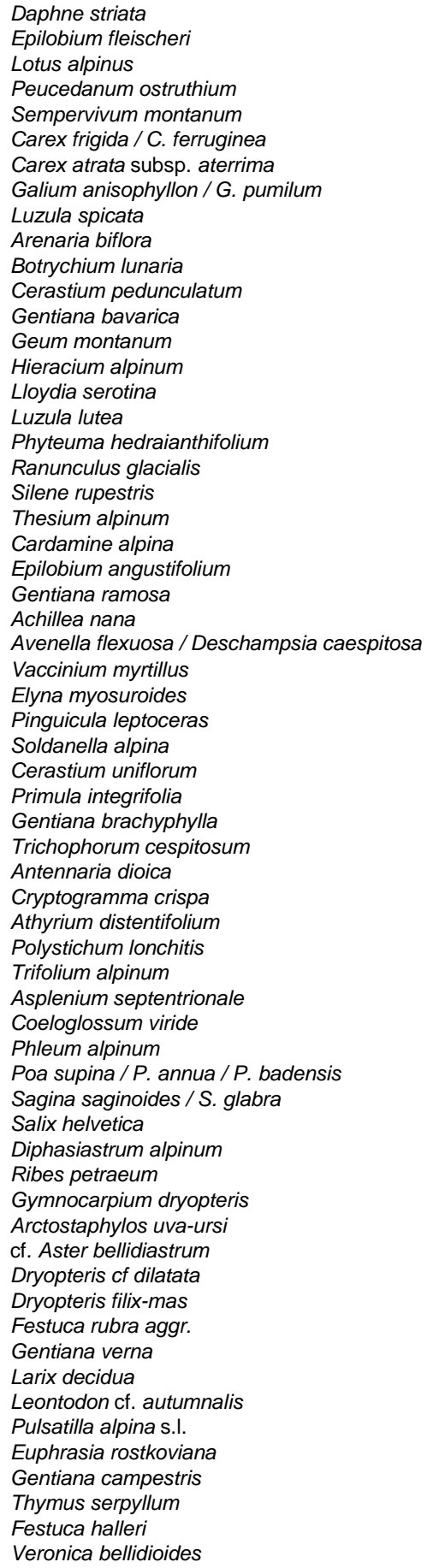

Additional species occurring only on the recently deglaciated area Species name

Androsace alpina / A. pubescens

Saxifraga oppositifolia

Saxifraga stellaris

Poa nemoralis

Arabis caerulea

Artemisia genipi

Salix glaucosericea

Salix hastata

Saxifraga exarata

Veronica fruticans

Arabis alpina

Epilobium anagallidifolium

Hieracium intybaceum

Salix retusa

Salix serpillifolia

Asplenium viride

1906

\begin{tabular}{|c|c|c|c|}
\hline \multicolumn{4}{|c|}{ Year } \\
\hline 1927 & 1972 & 1995 & 2003 \\
\hline 1 & 1 & 1 & 1 \\
\hline 1 & 1 & * & 1 \\
\hline 1 & 1 & * & 1 \\
\hline 1 & * & * & 1 \\
\hline & 1 & 1 & 1 \\
\hline & 1 & 1 & 1 \\
\hline & 1 & 1 & 1 \\
\hline & 1 & 1 & 1 \\
\hline & 1 & 1 & 1 \\
\hline & 1 & 1 & 1 \\
\hline & 1 & * & 1 \\
\hline & 1 & * & 1 \\
\hline & 1 & * & 1 \\
\hline & 1 & * & 1 \\
\hline & 1 & * & 1 \\
\hline & 1 & 1 & \\
\hline
\end{tabular}

Vittoz et al. (2008) 
Salix foetida

Saxifraga paniculata

Tussilago farfara

Linaria alpina

Erigeron cf. neglectus

Luzula cf. sudetica

Phyteuma betonicifolium

$\begin{array}{lll}1 & 1 & \\ 1 & 1 & \\ 1 & & \\ & 1 & 1 \\ & & 1 \\ & & 1 \\ & & 1\end{array}$

App. 2. Distribution of the 98 species present in 1906 and the 31 that arrived later on 9 growth-form types (Pignatti 2005; Illa et al. 2006): Th, therophytes; Hc ng, non-graminoid hemicryptophytes; Hc g, graminoid hemicryptophytes; $\mathrm{G}$, geophytes; $\mathrm{Ch}$ r, creeping chamaephytes; $\mathrm{Ch}$ cu, chamaephytes in cushion; Ch su, succulent chamaephytes; Ch wo, woody chamaephytes; $\mathrm{Ph}$, phaneophytes.

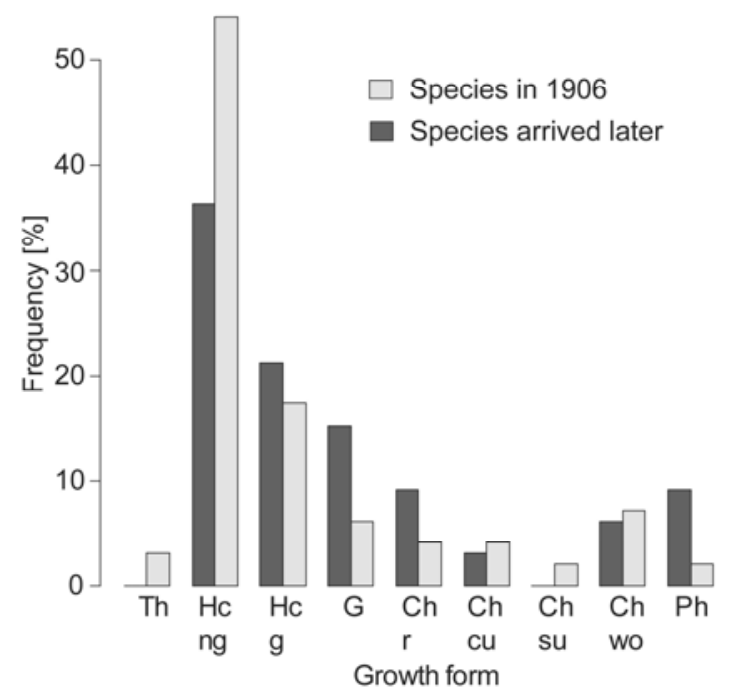

App. 3. Distribution of dispersal distance potential for the 98 species present in 1906 and the 31 that arrived later on 7 categories (Vittoz \& Engler in press): $1,99 \%$ of the seeds fall in a distance $<1 \mathrm{~m} ; 2$, $<5 \mathrm{~m} ; 3,<15 \mathrm{~m} ; 4,<150 \mathrm{~m} ; 5,<500 \mathrm{~m} ; 6,<1500 \mathrm{~m} ; 7,<5000 \mathrm{~m}$.

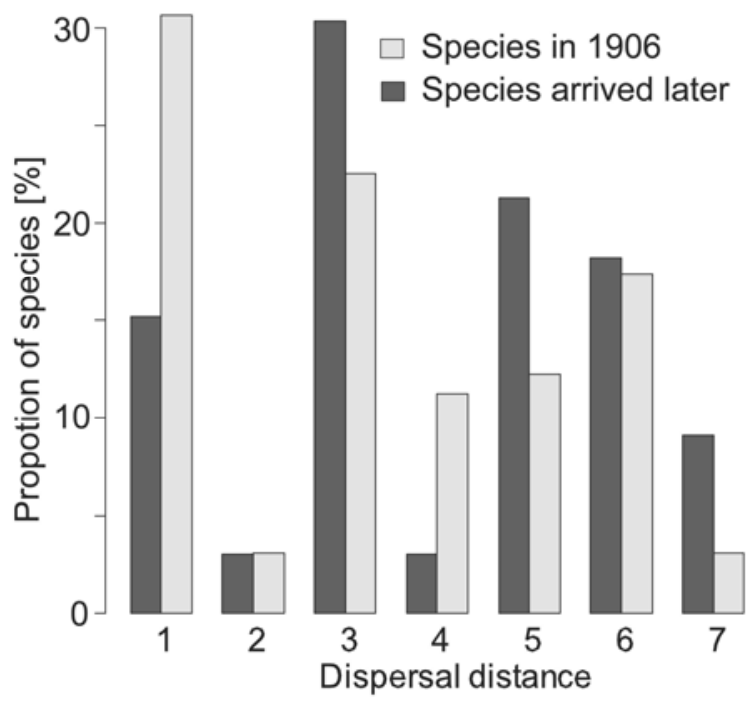

